\title{
FOTODEGRADASI PEWARNA TEKSTIL CONGO RED MENGGUNAKAN KATALIS ZnO/ZEOLIT Y SECARA SPEKTROFOTOMETRI UV-VIS
}

\author{
R. Supriyanto ${ }^{1 *}$, Regina Gita Riani Dio ${ }^{2}$, Syaiful Bahri ${ }^{1}$, Agung Abadi Kiswandono ${ }^{1}$ \\ ${ }^{1,2}$ Jurusan Kimia, FMIPA Universitas Lampung
}

\author{
r.supriyanto@gmail.com
}

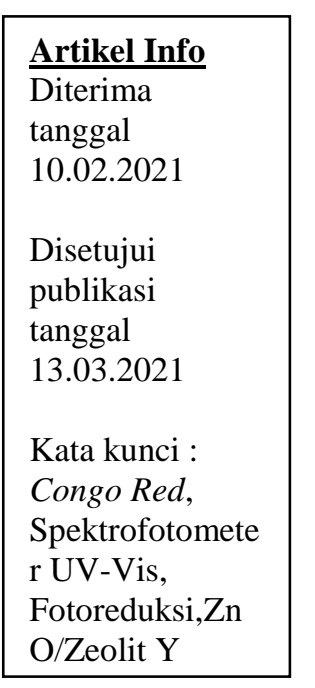

\begin{abstract}
ABSTRAK
Telah dilakukan penelitian fotodegradasi larutan pewarna tekstil Congo Red dengan menggunakan reaktor fotoreduksi lampu pijar 50 Watt dan menghasilkan kuat cahaya 8000 Lux, hasil degradasi warna dianalisis menggunakan Spektrofotometer UV-Vis. Pada penelitian ini dilakukan optimasi panjang gelombang optimum larutan Congo Red, pH larutan Congo Red, fotodegradasi dengan menambahkan zeolit Y, dan ZnO/Zeolit Y. Hasil penelitian diperoleh data karakterisasi terhadap katalis dengan metode Scanning Electron Microscopy (SEM) dan X-Ray Diffraction (XRD). Hasil pengukuran menggunakan Spektrofotometer UV-Vis diperoleh panjang gelombang optimum larutan pewarna Congo Red $498 \mathrm{~nm}$ dengan $\mathrm{pH}$ optimum pada $\mathrm{pH} 5$, degradasi warna Congo Red tanpa katalis terjadi pada waktu optimum 120 menit dengan persentase degradasi sebesar 21,68\%, penambahan katalis zeolit Y 0,6 mg dapat menurunkan intensitas warna Congo Red sebesar $63,30 \%$, sedangkan penambahkan $0,6 \mathrm{mg} \mathrm{ZnO/Zeolit} \mathrm{Y}$ dapat menurunkan intensitas warna Congo Red sebesar $78,01 \%$. Ada dua faktor utama terjadinya penurunan konsentrasi Congo Redyang lebih besar dibanding tidak ada penambahan
\end{abstract} zeolit-Y yaitu, penambahan zeolit-Y menyebabkan adanya adsorpsi Congo Redoleh zeolit-Y selain itu Congo Red yang tidak teradsorpsi oleh zeolit-Y mengalami proses fotoreduksi dengan bantuan sinar tampak.

\section{ABSTRACT}

Photodegradation of the dye solution was carried out Congo Red using a 50 Watt photoreduction lamp reactor and produced a light strength of 8000 Lux, the results of the color degradation were analyzed using a UV-Vis spectrophotometer. In this study, optimization of several variables were carry out including optimum wavelength of Congo Red, $\mathrm{pH}$ of solution Congo Red, photodegradation by adding zeolite Y, and ZnO/Zeolite Y. The results characterizedby Scanning Electron Microscopy (SEM) and XRay Diffraction (XRD). The measurement results using a UV-Vis Spectrophotometer are obtained optimum wavelength of the dye solution was Congo Red $498 \mathrm{~nm}$ with the optimum $\mathrm{pH}$ at $\mathrm{pH}$ 5, the color degradation of Congo Red without a catalyst occurred at the optimum time of 120 minutes with a degradation percentage of $21.68 \%$, the addition of $0.6 \mathrm{mg}$ of zeolite $\mathrm{Y}$ catalyst could reduce the color intensity of Congo Red was $63.30 \%$, while the addition of $0.6 \mathrm{mg} \mathrm{ZnO/Zeolite} \mathrm{Y} \mathrm{could} \mathrm{reduce} \mathrm{the} \mathrm{color}$ intensity of Congo Red by $78.01 \%$. There are two main factors that decrease the concentration of Congo Red which is greater than no addition of zeolite-Y, namely, the addition of zeolite-Y causes the adsorption of Congo Red by zeolite-Y. In addition, Congo Red which is not adsorbed by zeolite-Y undergoes a photoreduction process with the help of visible light.

http://dx.doi.org/10.23960/aec.v6.i2.2021.p104-113

Anal.Environ.Chem. 


\section{PENDAHULUAN}

Seiring dengan perkembangan teknologi, industri tekstil memproduksi pakaian dengan berbagai macam warna. Zat warna yang biasanya digunakan yaitu pewarna tekstil sintetik karena lebih murah, mudah didapatkan dan digunakan dibandingkan dengan pewarna alami. Selain berdampak positif bagi perekonomian masyarakat, industri tesktil ini juga menimbulkan dampak negatif. Dampak negatif yang ditimbulkan yaitu meningkatnya jumlah bahan pencemar dalam limbah cair yang dihasilkan dari tingginya pemakaian zat warna pada kegiatan industri tekstil tersebut (Nugroho dan Ikbal, 2005).

Salah satu jenis pewarna tekstil yang sering digunakan adalah Congo Red. Congo Red merupakan golongan zat warna azo yang memiliki gugus kromofor yang banyak digunakan dalam pencelupan kain terutama kain dari serat selulosa, rayon, dan wool. Hal ini karena zat warna azo dapat terikat kuat pada kain, sehingga tidak mudah luntur, memberikan warna yang baik dan tidak mudah rusak oleh perlakuan kimia (Blackburn and Burkinshaw, 2002). Keberadaan zat warna Congo Red dalam perairan dapat merusak berbagai spesies makhluk hidup karena sifat zat warna Congo Red yang mempunyai toksisitas cukup tinggi. Congo Red yang terakumulasi dalam tubuh dapat menyebabkan gangguan fungsi hati, ginjal,dan syaraf (Wardhana, 2004). Mengingat efek yang ditimbulkan oleh zat warna tekstil Congo Red terhadap lingkungan dan makhluk hidup di dalamnya, perlu dilakukan berbagai upaya untuk meminimalisir limbah zat warna tersebut sebelum dibuang ke dalam system perairan.

Semakin majunya teknologi berbagai teknik atau metode penanggulangan limbah tekstil telah dikembangkan, seperti metode adsorpsi. Metode ini dianggap kurang efektif karena zat warna tekstil yang diadsorpsi masih terakumulasi di dalam adsorben yang pada suatu saat nanti akan menimbulkan persoalan baru. Dari metode adsorpsi dikembangkan suatu metode untuk pengolahan zat warna tekstil yang dikenal dengan metode fotodegradasi. Fotodegradasi adalah suatu proses penguraian senyawa organik menjadi senyawa yang lebih sederhana dengan menggunakan bantuan energi foton dan radiasi sinar UV. Prinsipnya menggunakan fotokatalis yang berasal dari bahan semikonduktor, seperti $\mathrm{TiO}_{2}, \mathrm{ZnO}, \mathrm{Fe}_{2} \mathrm{O}_{3}, \mathrm{CdS}$, dan sebagainya (Sakhtivel et al., 2003). Semikonduktor $\mathrm{ZnO}$ memiliki keuntungan dibandingkan dengan $\mathrm{TiO}_{2}$ karena dia mampu menyerap spektrum matahari dan kuantum cahaya lebih banyak dibandingkan

http://dx.doi.org/10.23960/aec.v6.i2.2021.p104-113 
dengan $\mathrm{TiO}_{2}$. Material $\mathrm{ZnO}$ memiliki jarak celah pita yang lebih besar $(3,4 \mathrm{eV})$ daripada $\mathrm{TiO}_{2}$ sebesar 3,2 eV (Singh, 2009). Metode fotodegradasi akan meyebabkan zat warna terurai menjadi komponen-komponen yang lebih sederhana dan lebih aman untuk lingkungan. Dari uraian yang telah dipaparkan di atas maka dilakukan penelitian tentang fotodegradasi pewarna Congo Red menggunakan $\mathrm{ZnO} /$ Zeolit $\mathrm{Y}$ secara spektrofotometri UV-Vis, pada penelitian ini ditentukan panjang gelombang optimum, waktu optimum, $\mathrm{pH}$ optimum degradasi Congo Red, dan pengaruh penambahan katalis Zeolit-Y tanpa $\mathrm{ZnO}$ serta pengaruh penambahan katalis $\mathrm{ZnO} / \mathrm{Zeolit} \mathrm{Y}$.

\section{METODE}

\section{Alat dan Bahan}

Alat-alat yang akan digunakan dalam penelitian ini adalah alat-alat gelas dan alat pendukung lainnya, Spektrofotometer UV-Vis, pH meter, Scanning Electron Microscopy (SEM), XRD, reaktor fotodegradasi sinar tampak, pengaduk magnit, lux meter, tanur, dan neraca analitik.Bahan-bahan yang digunakan dalam penelitian ini adalah pewarna tekstil Congo Red, zeolit-Y, $\mathrm{ZnSO}_{4} 2 \mathrm{M}, \mathrm{ZnO} /$ Zeolit $\mathrm{Y}, \mathrm{H}_{2} \mathrm{SO}_{4}$ 0,01 M, $\mathrm{NaOH}$ 0,01 M dan akuades.

\section{Prosedur}

\section{Pembutan Larutan Baku Pewarna Congo Red}

a. ditimbang 1,0 gram pewarna Congo Red, dilarutkan menggunakan akuades dalam labu takar hingga tanda batas $1000 \mathrm{~mL}$. Diperoleh larutan pewarna tekstil Congo Red $1000 \mathrm{ppm}$.

b. diencerkan menjadi $50 \mathrm{ppm}$.

c. ditentukan panjang gelombang $(\lambda)$ optimum larutan pewaran tekstil Congo Red.

d. dibuat kurva kalibrasi dengan membuat variasi larutan baku 8, 12, 16, 20, dan 24 ppm. Ukur absorbansi deret larutan baku tersebut pada panjang gelombang optimum.

\section{Penyiapan Katalis $\mathrm{ZnO}$ /Zeolit $\mathrm{Y}$}

Ditimbang 5 gram Zeolit $\mathrm{Y}$ dan timbang $\mathrm{ZnSO}_{4}$ sebanyak 3,22 gram. $\mathrm{ZnSO}_{4}$ sebanyak 3,22 gram tersebut diencerkan dalam $100 \mathrm{~mL}$ akuabides, kemudian 2 bahan tersebut dimasukkan kedalam gelas kimia $400 \mathrm{~mL}$ lalu dan diaduk menggunakan magnetik stirer selama $\pm 2 \mathrm{jam}$, hasil tersebut kemudian dioven 24 jam pada suhu $80{ }^{\circ} \mathrm{C}$. Hasil oven di gerus menggunakan alu dan mortar sampai halus, kemudian serbuk $\mathrm{ZnO} /$ Zeolit $\mathrm{Y}$ tersebut sebagian dikalsinasi 2 jam pada 
suhu $600{ }^{\circ} \mathrm{C}$ dan sebagian di simpan dalam wadah botol film. Hasil kalsinasi di karakterisasi menggunakan XRD dan SEM.

\section{Penentuan Waktu Optimum Degradasi Congo Red}

$100 \mathrm{~mL}$ larutan pewarna Congo Red 16 ppm dimasukkan ke dalam reaktor fotoreduksi dan diaduk dengan kecepatan pengadukan 80 rpm dengan variasi waktu selama 0; 30; 60; 90; $120 ; 150 ; 180 ; 210$ dan 240 menit. diukur absorbansi larutan menggunakan spektrofometer UVVis, diperoleh waktu optimum degradasi Congo Red.

\section{Penentuan pH Optimum Degradasi Congo Red}

$100 \mathrm{~mL}$ larutan pewarna Congo Red 16 ppm diukur nilai pHnya menggunakan $\mathrm{pH}$ meter. Selanjutnya dengan menggunakan kuat cahaya dan waktu optimum yang telah diperoleh, kemudian ditentukan pengaruh $\mathrm{pH}$ dengan variasi $\mathrm{pH} 5,0 ; 6,0 ; 7,0 ; 8,0$ dan 9,0. Dengan penambahan $\mathrm{NaOH}$ 0,01 $\mathrm{M}$ dan $\mathrm{H}_{2} \mathrm{SO}_{4} 0,01 \mathrm{M}$ diukur absorbansi larutan, dan diperoleh $\mathrm{pH}$ optimum degradasi Congo Red.

\section{Pengaruh Penggunaan Katalis Zeolit-Y tanpaZnO}

$100 \mathrm{~mL}$ larutan pewarna tekstil Congo Red 16 ppm ditambahkan0,2;0,4;0,6;0,8; dan 1 mg Zeolit Y, kemudian dimasukkan kedalam reaktor fotoreduksi. Larutan hasil fotodegradasi dianalisis menggunakan spektrofotometer UV-Vis pada panjang gelombang $498 \mathrm{~nm}$.

\section{Pengaruh Penggunaan Katalis $\mathrm{ZnO/Zeolit} \mathrm{Y}$}

Dengan menggunakan kuat cahaya, waktu dan pH optimum.100 mL larutan pewarna tekstil Congo Red 16 ppm ditambahkan0,2;0,4;0,6;0,8; dan 1 mg ZnO/Zeolit Y, dimasukan kedalam reaktor fotoreduksi. Kemudian larutanhasil fotodegradasi dianalisis menggunakan spektrofotometer UV-Vis pada panjang gelombang $498 \mathrm{~nm}$.

\section{HASIL DAN PEMBAHASAN}

\section{Penentuan Panjang Gelombang Optimum Larutan Congo Red}

Pada penelitian ini dilakukan penentuan panjang gelombang optimum senyawa Congo Red dalam larutan, penentuan panjang gelombang ini diperlukan untuk memenuhi persyaratan hukum Beer pada bidang analitik, ada tiga syarat utama berlakunya hukum Beer yaitu yaitu larutan harus encer, berwarna atau tidak berwarna tetapi harus jernih, tidak terjadi reaksi lanjut. Untuk memenuhi syarat tersebut pada penelitin ini dilakukan dengan membuat larutan Congo 
Red pada konsentrasi 50 ppm, dan ditelusur (scan) pada rentang panjang gelombang dari $400 \mathrm{~nm}$ hingga $600 \mathrm{~nm}$ menggunakan Spektrofotometer UV-Vis Merk HITACHI modelU 2000. Hasil pengukuran diperoleh panjang gelombang optimum Congo Red pada $498 \mathrm{~nm}$. Hal ini sesuai dengan Tapalad et al., (2008) dimana Spektra Congo Red menunjukkan karakter pada puncak sekitar $498 \mathrm{~nm}$. Pada panjang gelombang tersebut menunjukkan bahwa Congo Reddapat digunakan untuk analisis selanjutnya dalam melakukan validasi metode dan aplikasinya.

\section{Penyiapan Katalis Zeolit-Y-ZnO}

Zeolit-Y-ZnO dibuat dengan metode impregnasi, dengan cara melarutan $\mathrm{ZnSO}_{4}$ sebanyak 3,22 gram dalam Erlenmeyer berisi $100 \mathrm{ml}$ aquabides dan 5,0 gam zeolit-Y kemudian dilakukan pemanasan serta pengadukan selama 2 jam hal ini supaya ion $\mathrm{Zn}^{2+}$ dapat masuk ke dalam poripori zeolit, lalu ditambahkan $\mathrm{NaOH}$ untuk membuat kondisi larutan menjadi basa. Dilanjutkan dengan pemanasan serta pengadukan selama 2 jam. Kemudian dilakukan pengeringan menggunakan oven selama 24 jam pada suhu $80^{\circ} \mathrm{C}$ agar zeolit-Y-ZnO terpisah dari larutannya. Hasil yang diperoleh kemudian dihaluskan hingga menghasilkan serbuk dan dikalsinasi selama 2 jam (setelah suhu tanur stabil) pada suhu $600{ }^{\circ} \mathrm{C}$ proses kalsinasi sendiri dilakukan agar senyawa organik yang terdapat pada rongga terurai.

\section{X-Ray Diffraction (XRD)}

Katalis zeolit-Y-ZnO dianalisis dengan metode XRD pada sudut $60^{\circ} \mathrm{C}$, analisis dilakukan di Laboratorium Metalurgi Institut Teknologi Surabaya, Surabaya.Karakterisasi katalis zeolit-Y$\mathrm{ZnO}$ dengan XRD bertujuan untuk mengidentifikasi struktur, fasa katalis, serta pembentukan fasa kristalin atau amorf pada katalis zeolit-Y-ZnO berdasarkan letak sudut $0-60^{\circ}$. Hasil karakterisasi XRD setelah kalsinasi dapat dilihat pada Gambar 1.

Dari data XRD zeolit-Y-ZnO yang diperoleh telihat bahwa munculpuncakyaitu pada sudut $2 \theta=$ 21,2917; 23,1986;27,3616;31,7237;32,3979;45,4640; dan 56,5037. Puncak khas ZnO berdasarkandata standar JCPDS no. 0036-1451 muncul pada $2 \theta=31,8 ; 34,42 ; 36,26 ; 47,54$; dan 56,50, ukuran kristal katalis zeolit-Y-ZnO dihitung dengan persamaan Scherrer sehingga didapatkan ukuran kristal sebesar 83,173 nm. Berdasarkan perhitungan tersebut ukuran kristal berukuran nanokristal karena berada pada rentang 10-200 nm.

http://dx.doi.org/10.23960/aec.v6.i2.2021.p104-113 


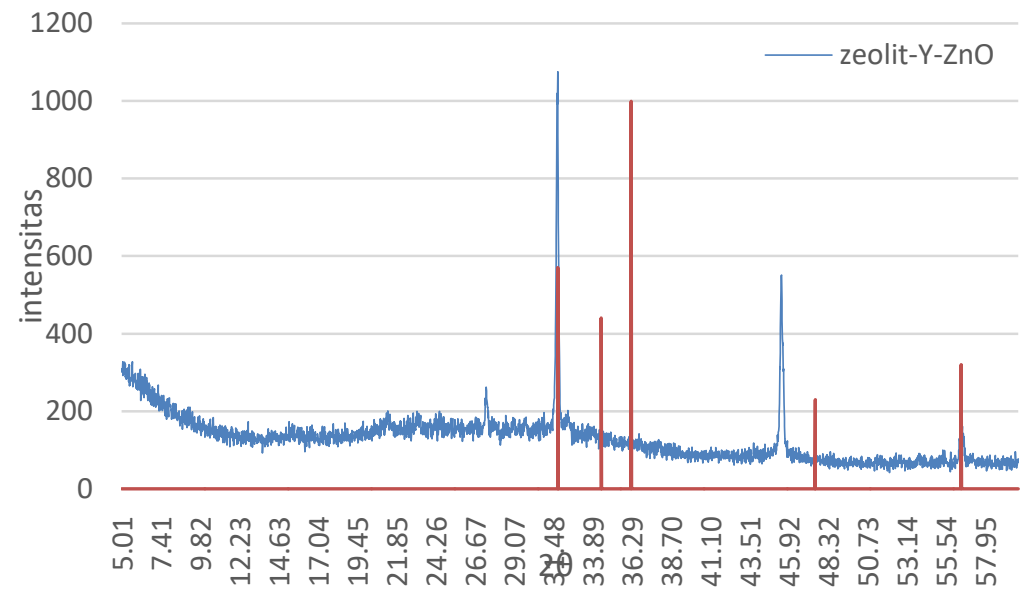

Gambar 1. Difraktogram Sinar-X katalis zeolit-Y-ZnO.

\section{Penentuan Waktu Optimum Degradasi Larutan Congo Red}

Penelitian ini dilakukan dengan cara larutan pewarna Congo Red sebanyak $100 \mathrm{~mL}$ dengan konsentrasi $16 \mathrm{ppm}$, diletakan sedemikian rupa kedalam reaktor fotodegradasi yang sudah dilengkapi lampu pijar 50 watt dan pengaduk magnet. Lampu dinyalakan dengan kuat cahaya 8000 Lux, dianalisis selama 240 menit dengan rentang waktu 30 menit. Hasil yang diperoleh setiap 30 menit dianalisis menggunakan Spektrofotometer UV-Vis Hitachi U 2000 dengan hasil sebagai berikut pada Gambar 2.

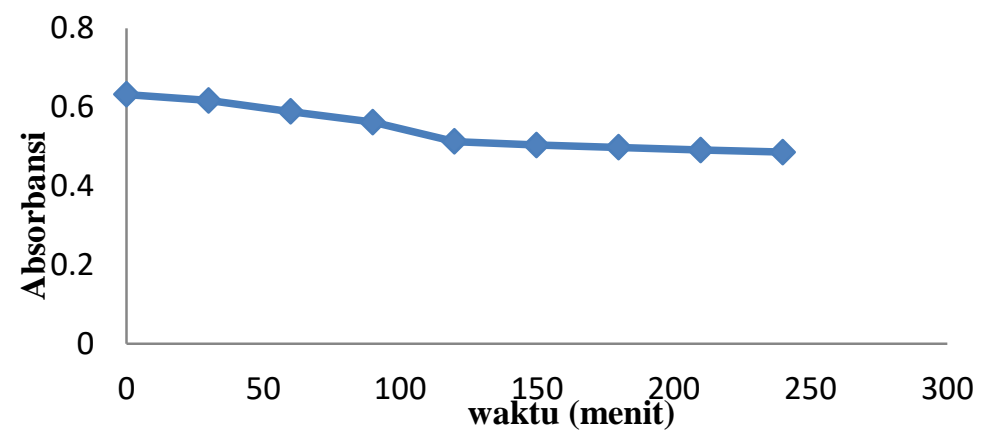

Gambar 2. Penentuan Waktu Optimum

Dari data dan gambar 2 menunjukan bahwa penurunan konsentrasi yang signifikan terjadi pada proses fotoreduksi menit 90 hingga 120 terlihat nilai penurunan mencapai 9,6\%. Dari data juga menunjukkan bahwa semakin lama proses fotodegradasi terhadap Congo Red dilakukan, penurunan konsentrasi Congo Red juga terus terjadi dengan penurunan konsentrasi sebesar 21,68 
$\%$. Dari hasil penelitan yang diperoleh dapat dilihat bahwa waktu optimum yang didapat lebih efektif digunakan dan lebih cepat. Sedangkan penelitian yang dilakukan oleh Saraswati, dkk., waktu optimum yang diperoleh adalah 5 jam. Semakin lama waktu radiasi sinar UV maka semakin banyak foton/energi yang mengenai permukaan $\mathrm{ZnO}$ sehingga diperoleh persentasi degradasi semakin besar (Subagio dan Nurhasanah, 2011). Hal yang sama juga ditemukan pada penelitian Attia, et al (2007) yang menyatakan bahwa semakin meningkat waktu radiasi sinar UV maka persentase degradasi (\%D) semakin besar.

\section{Penentuan pH Larutan Congo RedTerhadap Fotodegradasi}

$100 \mathrm{~mL}$ larutan Congo Red 16 ppm dengan variasi pH 5,0; 6,0; 7,0; 8,0; 9,0 ditambahkan larutan $\mathrm{NaOH}$ atau $\mathrm{HCl}$ pada akubides hingga $\mathrm{pH}$ yang diinginkan. Selanjutnya dilakukan fotodegradasi dan diukur absorbansi dari masing-masing larutan selama 240 menit dengan rentang waktu 30 menit.

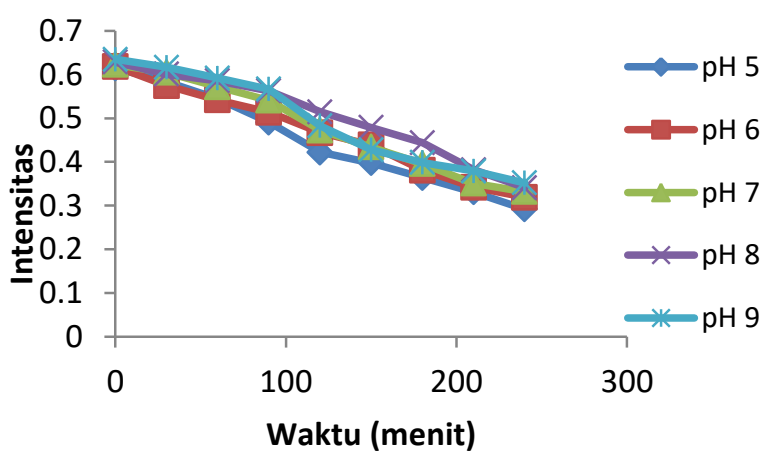

(a)

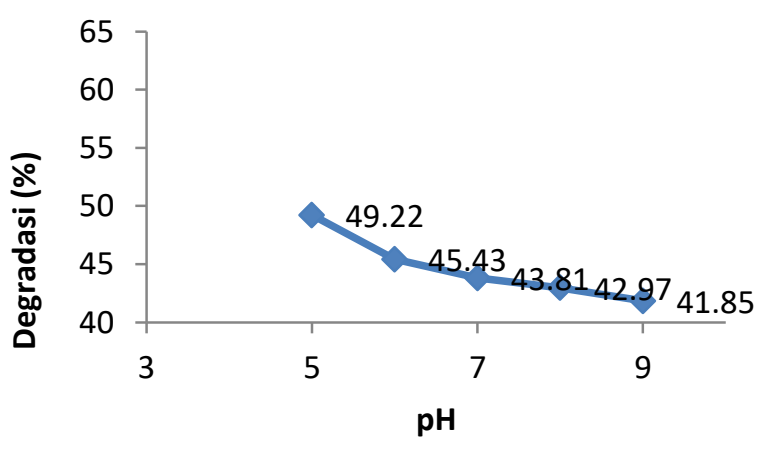

(b)

Gambar 3. (a) Grafik pengaruh pH pada fotoreduksi Congo Red di setiap variasi pH (b) Grafik persen penurunan konsentrasi pada variasi $\mathbf{p H}$

Dari hasil analisis larutan Congo Red mengunakan Spektrofotometer UV-Vis pada setiap waktu dengan selang waktu 30 menit pada setiap pH larutan, setelah diamati menunjukkan pada pH 5,0 memberikan penurunan warna Congo Red yang cukup signifikan dengan penurunan intensitas warna sekitar 49,22\% selama 120 menit. Dengan demikian,pada kondisi asam semakin banyak 
jumlah zatwarna congo red yang teradsorpsi pada permukaan $\mathrm{ZnO}$, semakin banyak pula congo red yang terdegradasi oleh fotokatalis ini. Hal yang sama juga didapatkan oleh Saraswati, dkk dimana hasil yang diperoleh pada $\mathrm{pH} 4$ dengan persentase degradasi diperoleh sebesar 87,87\% dan Wijaya et al., (2006) yang menunjukkan bahwa fotodegradasi zat warna Congo Red lebih baik terjadi dalam suasana asam.

\section{Pengaruh Penambahan Katalis Zeolit Y Dalam Proses Fotodegradasi}

Hasil analisis dan pengamatan pengaruh penambahan katalis zeolit y dalam proses fotodegradasi dapat dilihat pada Gambar 5.

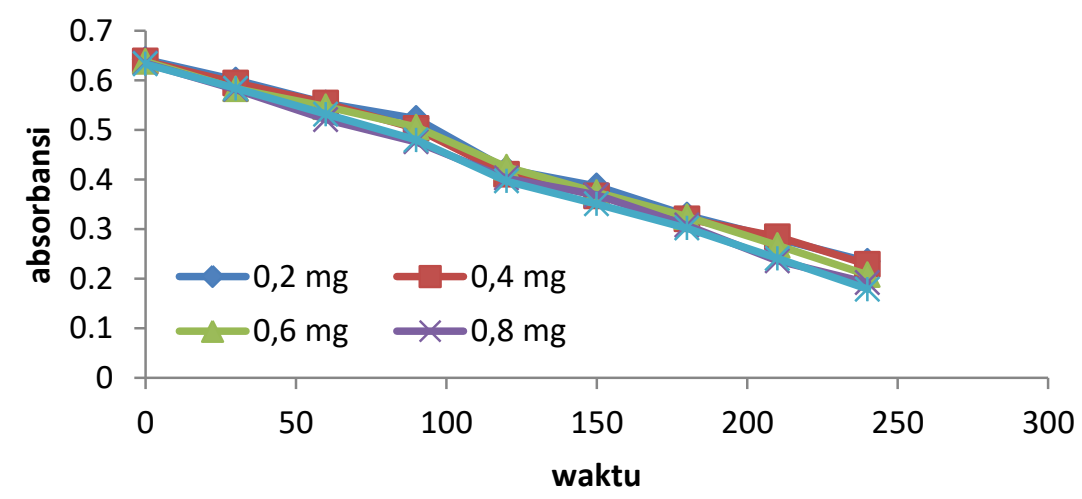

Gambar 5. Grafik pengaruh penambahan zeolit-Y terhadap fotoreduksi

Dari data yang telah didapat menunjukkan bahwa semakin banyak penambahan zeolit-Y maka semakin besar penurunan konsentrasi Congo Red. Dilihat dari Gambar 6 penurunan signifikan terjadi setelah penambahan $0,6 \mathrm{mg}$ katalis zeolit Y sebanyak 63,30\%. Ada dua faktor utama terjadinya penurunan konsentrasi Congo Redyang lebih besar dibanding tidak ada penambahan zeolit-Y yaitu, penambahan zeolit-Y menyebabkan adanya adsorpsi Congo Red oleh zeolit-Y selain itu Congo Redyang tidak teradsorpsi oleh zeolit-Y mengalami proses fotoreduksi dengan bantuan sinar tampak. 


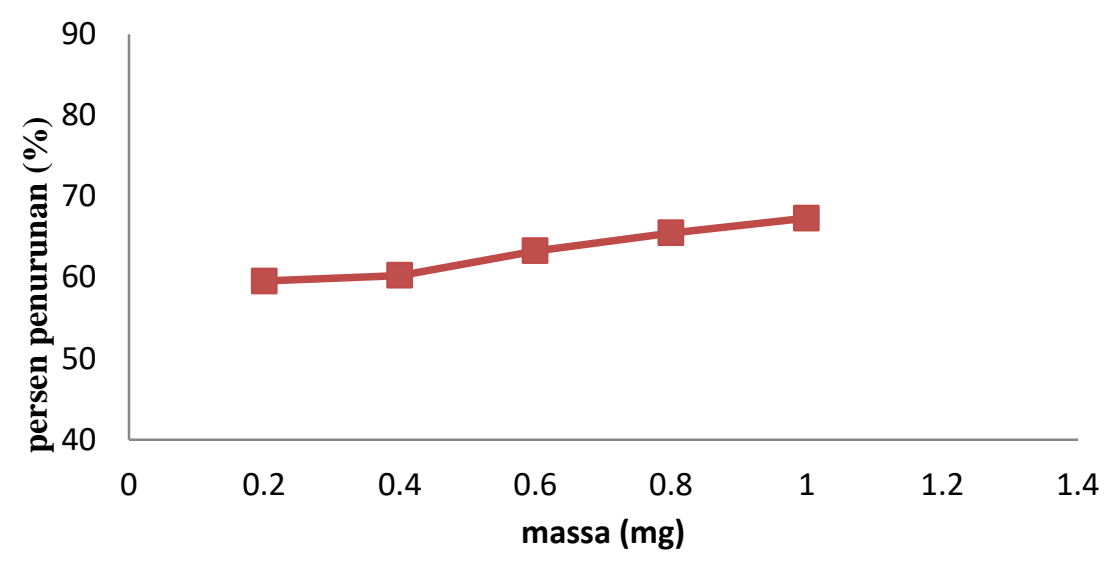

Gambar 6. Grafik persen penurunan konsentrasi pada variasi penambahan zeolit-Y

\section{KESIMPULAN}

1. Hasil pengukuran menggunakan Spektrofotometer UV-Vis diperoleh panjang gelombang optimum Congo Red pada $498 \mathrm{~nm}$.

2. $\mathrm{pH}$ optimum yang diperoleh dari hasil fotodegradasi adalah $\mathrm{pH} 5$ dengan persen penurunan sebesar 49,22\%.

3. Waktu optimum yang diperoleh pada proses fotodegradasi adalah 120 menit dengan persentase sebesar $9,62 \%$.

4. Fotodegradasi menggunakan reaktor fotoreduksi dengan penambahan zeolit-Y 0,6 mg, pH 5,0 selama 120 menit menghasilkan penurunan intensitas warna larutan sebesar 63,30\%.

5. Fotodegrdasi menggunakan reaktor fotoreduksi dengan penambahan katalis $\mathrm{ZnO} / \mathrm{Zeolit} \mathrm{Y} \quad 0,6$ $\mathrm{mg}$, selama 120 menit, $\mathrm{pH}$ 5,0, menghasilkan penurunan intensitas larutan pewarna Congo $\operatorname{Red} 78,01 \%$.

\section{DAFTAR PUSTAKA}

Attia, A.J., Kadhim,S.H., and Hussen, F. H., 2007, Phoyocataliytc Degradation of Textile Dyeing Wastewater Using Titanium Dioxide and Zinc Oxide, E-Journal of Chemistry, 2 : 219-223

http://dx.doi.org/10.23960/aec.v6.i2.2021.p104-113 
Blackburn, R.R. And S.M. Burkinshaw, 2002, A Greener to Cotton Deing With Excellent Wash Fastness, Green Chem., (4): 47-52.

Nugroho R dan Ikbal., 2005, Pengolahan Air Limbah Berwarna Industri Tekstil dengan Proses AOPs. JAI., 1(2): 153-172.

Sakthivel, S., Neppolian, B., Shankar, V., Arabindoo, B., Palanichamy, M. dan Murugesen, V., 2003, Solar Photocatalytic Degradation of Azo Dye Comparison of Photocatalytic Efficiency of $\mathrm{ZnO}$ and $\mathrm{TiO}_{2}$, Solar Energy Materialand Solar Cell., 77:65-82.

Saraswati, I Gusti Ayu Adesia., Ni Putu Diantariani., dan Putu Suarya, 2015, Fotodegradasi Zat Warna Tekstil Congo Red Dengan Fotokatalis ZnO-Arang Aktif Dan Sinar Ultraviolet (UV), Jurnal Kimia., 9 (2):175-182.

Singh, S., 2009, Electrical Transport and Optical Studies of Transition Metal Ion Doped ZnO and Synthesis of ZnO based Nanostructure by Chemical Route, Thermal Evaporation and Pulsed Laser Deposition, Thesis, Departmen Of Physics Indian, Institute Of Technology Madras.

Subagio, F.A.A. dan Nurhasanah, I., 2011, Sintesis Nanokomposit TiO2 - Carbon Nanotubes Menggunakan Metode Sol-Gel untuk Fotodegradasi Zat Warna Azo Orange 3R, Jurnal Ilmu Pengetahuan dan Teknologi, 29 (2) : 63-72

Tapalad, T., Neramittagapong, A., Neramittagapong, S., Boonmee, M., 2008, Degradation of Congo red dye by ozonation., Chiang Mai J. Sci., 35 (1):63-68

Wardhana, W. A., 2004, Dampak Pencemaran Lingkungan, Cetakan keempat, Penerbit ANDI, Yogyakarta.

Wijaya, K., Sugiharto, E., Fatimah, I., Sudiono, S., dan Kurniaysih, D., 2006, Utilisasi TiO2Zeolit Dan Sinar UV Untuk Fotodegradasi Zat Warna Congo Red, Berkala MIPA, 3 : 27 35 